\title{
STUDI FUNGSI PENGAMAN PANTAI DI PESISIR TELUK MANADO
}

\author{
Jeffrey Andre Delarue \\ Teknik Sipil, Fakultas Teknik, Universitas Negeri Manado \\ e-mail: jefrreydelarue@unima.ac.id
}

\begin{abstract}
This research is based on knowing the function of the performance of the coastal protection building at several points on the coast of Manado Bay. Determination of the performance function of the coastal protection is one of the parameters that indicate whether it is still functioning properly or not so that through performance monitoring actions can be taken to improve the function of the coastal protection structure. The function of the coastal protection building performance is carried out by direct observation with survey methods and the data analysis process uses a descriptive approach. The location of the research was carried out in the Port of Manado, the KFC area on Megamas Region, and Sindulang Beach. The results of the field survey show that the safety function of the Tetrapod beach building which is located in the Manado Port area is classified as good, the foot of the beach building, the middle part, and the top of the beach building are still arranged in good condition which is very useful to protect ships and surrounding buildings. The performance function of the safest building in the area around KFC in the Megamas area shows good performance but it needs maintenance because it has shown loose rocks in the middle of the coastal protection building. Meanwhile, in the Sindulang Beach area, the performance function of the coastal protection structure has decreased, which is shown at the end of the beach protection which appears to be detached from the main part. Likewise, with the middle part of the coastal protection building, there are parts of the rock that are starting to come off. Actions that need to be taken are maintenance of coastal protection structures and cleaning of garbage so that the performance of the beach protection around the coast of Manado Bay can function properly.
\end{abstract}

Keywords: : Function, Performance, Beach Safety, Manado Bay

\begin{abstract}
Abstrak: Penelitian ini didasari untuk mengetahui fungsi kinerja bangunan pengaman pantai pada beberapa titik di Pesisir Teluk Manado. Penentuan fungsi kinerja pengaman pantai merupakan salah satu parameter yang mengindikasikan apakah masih berfungsi dengan baik atau tidak, sehingga melalui pemantauan kinerja dapat diambil tindakan untuk memperbaiki fungsi dari bangunan pengaman pantai. Fungsi kinerja bangunan pengaman pantai dilakukan dengan pengamatan secara langsung dengan metode survei dan proses analisis data menggunakan pendekatan deskriptif. Lokasi penelitian dilakukan di Pelabuhan Manado, Daerah KFC Kawasan Megamas dan Pantai Sindulang. Hasil survei lapangan, menunjukan fungsi pengaman bangunan pantai Tetrapod yang terletak di daerah Pelabuhan Manado tergolong baik, kaki bangunan pantai, bagian tengah dan bagian atas bangunan pantai masih tersusun dengan kondisi baik yang sangat bermanfaat untuk melindungi kapal-kapal dan bangunan di sekitar. Fungsi kinerja bangunan pengaman di daerah sekitar KFC pada Kawasan Megamas menunjukkan kinerja yang baik tapi perlu dilakukan pemeliharaan, karena telah menunjukkan adanya batuan yang terlepas pada bagian tengah bangunan pengaman pantai. Sedangkan di daerah Pantai Sindulang, fungsi kinerja bangunan pengaman pantai telah mengalami penurunan yang ditunjukkan pada bagian ujung pengaman pantai tampak mulai terlepas dari bagian induk. Begitu juga dengan bagian tengan bangunan pengaman pantai, terdapat bagian-bagian batuan yang mulai terlepas. Tindakan yang dapat perlu dilakukan adalah pemeliharan bangunan pengaman pantai dan pembersihan sampah agar kinerja pengaman pantai di sekitar pesisir teluk manado dapat berfungsi dengan baik.
\end{abstract}

Kata Kunci: Fungsi, Kinerja, Pengaman Pantai, Teluk Manado

\section{PENDAHULUAN}

Perlindungan pantai dapat ditimbulkan secara alami oleh pantai maupun dengan bantuan manusia. Perlindungan pantai secara alami dapat berupa dunes maupun karang laut ataupun lamun yang tumbuh secara alami. 